\title{
Effect of Sulphur and Boron on Yield, Quality, Nutrient Uptake and Post-Harvest Soil Nutrient Status of Hybrid Sunflower
}

\author{
*Kalaiyarasan.C' ${ }^{1}$, D.Tamizhselvan ${ }^{1}$, S.Jawahar ${ }^{1}$, S. Ezhilkumar², K.Suseendran ${ }^{1}$, S. Madhavan ${ }^{3}$ \\ and S. Ramesh ${ }^{1}$ \\ ${ }^{1}$ Department of Agronomy, ${ }^{2}$ Department of Genetics and Plant Breeding, \\ ${ }^{3}$ Department of Horticulture, Faculty of Agriculture, Annamalai University, \\ Annamalai Nagar - 608 002, Tamil Nadu, India. \\ *Corresponding author: email id: kalai77.agri@gmail.com
}

\begin{abstract}
The Field investigations were conducted in two locations viz., at Experimental Farm, Department of Agronomy, Faculty of Agriculture, Annamalai University, Annamalai Nagar, Tamil Nadu during March - June 2013 and at farmers field at Ko-Chathiram village, Kurinjipadi block, Cuddalore district, Tamil Nadu during July- October 2013 to study the effect of different levels of sulphur and boron on quality characters, nutrient uptake and post-harvest soil nutrient status of hybrid sunflower cv. Sunbred. The treatment consisted of sulphur with five levels $\left(0,15,30,45,60 \mathrm{~kg} \mathrm{~S}^{-1}\right)$ and three levels of boron $(0$, $\left.0.5,1.0 \mathrm{~kg} \mathrm{~B} \mathrm{ha}^{-1}\right)$. Totally fifteen treatments were tested and were laid out in factorial concept of randomized block design with three replication. The results revealed that growth, yield attributes and yield was significantly influenced by various S and B levels. Among the treatment combinations tried, $60 \mathrm{~kg} \mathrm{~S} h a^{-1}$ with B @ $1 \mathrm{~kg} \mathrm{ha}^{-1}$ has a spectacular effect on quality characters, nutrient uptake, ultimately leading to maximum seed yield (2573.25 and $\left.2673.84 \mathrm{~kg} \mathrm{ha}^{-1}\right)$ in both the crops. S @ $0 \mathrm{~kg} \mathrm{ha}^{-1}$ with B @ $0 \mathrm{~kg} \mathrm{ha}^{-1}$ recorded maximum availability of N, P, K and S was noticed under S $15 \mathrm{~kg} \mathrm{ha}^{-1}$ with B @ 1.0 $\mathrm{kg} \mathrm{ha}^{-1}$ during both the crops. The lowest values of quality characters, nutrient uptake were recorded by $0 \mathrm{~kg} \mathrm{Sha}{ }^{-1}$ with B @ $1 \mathrm{~kg} \mathrm{ha}^{-1}$.
\end{abstract}

DOI: $10.7176 / \mathrm{JSTR} / 5-11-01$

\section{Introduction:}

Among the oilseed crops, sunflower (Helianthus annuus L.) is an all season crop. Holds great promise as an oilseed crop because of its short duration, photo-in-sensitivity and wide adaptability to different agro-climatic regions and soil types. Sunflower seed contains about 48-53 percent edible oil. Sunflower oil is a rich source of linoleic acid (64 percent) which is good for heart patients. The oil is also used for manufacturing hydrogenated oil. Sunflower can play an important role in meeting out the shortage of edible oils in the country. With the improvement of crop productivity through the adoption of highyielding varieties and multiple cropping systems, fertilizer use has become more and more important to increase crops yield and quality. After N, P and K, S is the fourth nutrient, whose deficiency is widespread in India (Sakal et al., 2001). Sulphur deficiency is observed primarily due to high crop yield and therefore higher rate of S removal by crops, and lesser use of S containing fertilizers (Messick, 2003). $\mathrm{S}$ is an essential plant nutrient for crop production. For oil crop producers, $\mathrm{S}$ fertilizer is especially important because oil crop require more $\mathrm{S}$ than cereal grains. $\mathrm{S}$ is best known for its role in the formation of amino acids methionine $(21 \% \mathrm{~S})$ and cysteine $(27 \% \mathrm{~S})$; synthesis of proteins and chlorophyll; oil content of the seeds and nutritive quality of forages (Jamal et al., 2005). An sufficient S supply can affect yield and quality of the crops, caused by the $S$ requirement for protein and enzyme synthesis as well it is a constituent of the amino acids, methionine and cysteine. As like sulphur, boron (B) is also one of the micronutrients required for normal growth and development of many crops. The role of B in plant has been proposed including functions in cell wall structure, cell wall synthesis sugar translocation, cell division, enzymatic reactions and plant growth regulation (Blevins and Lukaszewski, 1998). Sunflower is one of the most sensitive crops to B deficiency. B deficiency symptoms in sunflower become evident on leaves, stems, reproductive parts, dry matter, yield components and seed yield (Blamey et al., 1997). Asad et al. (2002) reported that B requirement of sunflower during reproductive growth is higher than during vegetative growth. Boron foliar spray may help in the processes of pollination and better seed

1 I $\mathrm{P}$ a g e

www.iiste.org 
filling of sunflower. With above said points, the experiment was conducted to enhance yield, quality, nutrient uptake and post harvest soil nutrient status of sunflower by using sulphur and boron.

\section{Materials and Methods:}

Field investigations were conducted during March - June 2013 at Experimental Farm, Department of Agronomy, Faculty of Agriculture, Annamalai University, Annamalai Nagar, Tamil Nadu and at farmers field at Ko-Chathiram village, Kurinjipadi block, Cuddalore district, Tamil Nadu during July- October 2013. The soil of the experimental field is clay loam and sandy clay loam in texture. The nutrient status of the experimental soil was low in nitrogen, medium in phosphorus, high in potassium and low in sulphur. Sunflower hybrid sunbred was chosen for this study. The experiment consisted of fifteen treatments and was laid out in factorial randomized block design with three replications. The treatments imposed in the experiment are different sulphur levels $\left(0,15,30,45,60 \mathrm{~kg} \mathrm{~S} \mathrm{ha}^{-1}\right)$ through gypsum were tried along with different boron levels $\left(0,0.5,1.0 \mathrm{~kg} \mathrm{~B} \mathrm{ha}^{-1}\right)$ through Borax. Recommended dose of 60:90:60 kg of N, P and $\mathrm{K} \mathrm{ha}^{-1}$ was applied in the form of Urea and DAP and MOP respectively. Half the dose of $\mathrm{N}$ and entire dose of $\mathrm{P}$ and $\mathrm{K}$ were applied basally. The remaining quantity of $\mathrm{N}$ was applied at 30 DAS.

\section{Result and Discussion: Yield attributes (Table 1)}

Application of sulphur influenced significantly the yield attributes in both crops. Application of $60 \mathrm{~kg} \mathrm{~S}$ $\mathrm{ha}^{-1}$ significantly increased the head diameter, number of seeds head ${ }^{-1}$, number of filled seeds head ${ }^{-1}$, seed filling percent and 100 seed weight over other levels. Sulphur is known to play a vital role in the formation of amino acids, had favourable effect on yield attributes due to proper portioning of photosynthetic from source to sink. These findings are in conformity with reports of Syed Shuja Hussain et al. (2011).

Boron levels significantly influenced the yield attributes in both crops. Application of boron @ 1 kg B $\mathrm{ha}^{-1}\left(\mathrm{~B}_{2}\right)$ significantly influenced the yield attributes over other levels. This might be due to the role of boron in cell elongation, photosynthesis, translocation of sugars and transpiration. These results are in harmony with those obtained by Renukadevi et al. (2003).

The interaction between sulphur and boron levels was found significant in both the crops. The higher seed yield was registered under the treatment combination of $S_{4} B_{2}\left(60 \mathrm{~kg} \mathrm{~S} \mathrm{ha}^{-1}\right.$ with $\left.\mathrm{B} @ 1 \mathrm{~kg} \mathrm{ha}{ }^{-1}\right)$. This might be due to availability of sulphur, boron and other nutrients at both vegetative and reproductive stages. These findings were earlier reported by Raja et al. (2007).

\section{Yield (Table 1)}

Application of S @ $60 \mathrm{~kg} \mathrm{ha}^{-1}$ recorded maximum seed yield of 2115.59 and $2215.95 \mathrm{~kg} \mathrm{ha}^{-1}$ and stalk yield of 4180.03 and $4273.20 \mathrm{~kg} \mathrm{ha}^{-1}$ in first and second crops, respectively. The yield increase might be also due to increased growth, which resulted in increased photosynthesis and assimilation rates, cell division which turn in increased the seed yield. Sulphur application increased the chlorophyll content in leaf gave significant positive correlation between chlorophyll content in leaf crop yield (Sinha et al., 1995).

Boron levels significantly influenced the seed and stalk yield in both the crops. Application of B @ $1 \mathrm{~kg}$ $\mathrm{ha}^{-1}$ recorded the maximum seed yield of 2001.00 and $2102.03 \mathrm{~kg} \mathrm{ha}^{-1}$ and stalk yield of 3932.01 and $4038.80 \mathrm{~kg} \mathrm{ha}^{-1}$ in first and second crop, respectively. This is due to the role of boron in cell division, sugar transport and hormone development (Khalifa, 2005).

The interaction effects between sulphur and boron levels was significant. Application of $\mathrm{S}_{4} \mathrm{~B}_{2}(60 \mathrm{~kg} \mathrm{~S}$ ha $^{-1}$ with B @ $1 \mathrm{~kg} \mathrm{ha}^{-1}$ ) recorded higher seed yield (2573.25 and $2673.84 \mathrm{~kg} \mathrm{ha}^{-1}$ ) and stalk yield (4582.73 and $4689.73 \mathrm{~kg} \mathrm{ha}^{-1}$ ) in both the crops. Increased seed yield due to application of sulphur and boron was reported by Sumathi et al. (2005). 
International Journal of Scientific and Technological Research ISSN 2422-8702 (Online), DOI: 10.7176/JSTR/5-11-01

Vol.5, No.11, 2019 www.iiste.org

팔

Table 1: Effect of different levels of sulphur and boron on yield attributes and yield of sunflower

\begin{tabular}{|c|c|c|c|c|c|c|c|c|c|c|c|c|c|c|}
\hline \multirow[t]{2}{*}{ Treatments } & \multicolumn{2}{|c|}{$\begin{array}{l}\text { Head diameter } \\
(\mathbf{c m})\end{array}$} & \multicolumn{2}{|c|}{$\begin{array}{l}\text { Number of seeds } \\
\text { head }^{-1}\end{array}$} & \multicolumn{2}{|c|}{$\begin{array}{l}\text { Number of filled } \\
\text { seeds head }{ }^{-1}\end{array}$} & \multicolumn{2}{|c|}{$\begin{array}{l}\text { Seed filling } \\
\text { percent }\end{array}$} & \multicolumn{2}{|c|}{$\begin{array}{c}100 \text { seed weight } \\
\text { (g) }\end{array}$} & \multicolumn{2}{|c|}{ Seed yield $\left(\mathrm{Kg} \mathrm{ha}^{-1}\right)$} & \multicolumn{2}{|c|}{ Stalk yield $\left(\mathrm{Kg} \mathrm{ha}^{-1}\right)$} \\
\hline & I crop & II Crop & I crop & II Crop & I crop & II Crop & I crop & II Crop & I crop & II Crop & I crop & II Crop & I crop & II Crop \\
\hline \multicolumn{15}{|l|}{ Sulphur } \\
\hline $\mathbf{S}_{\mathbf{0}}$ & 13.25 & 15.15 & 640.33 & 666.51 & 504.01 & 530.13 & 78.64 & 79.48 & 5.54 & 5.45 & 1109.39 & 1209.42 & 3207.73 & 3307.39 \\
\hline $\mathbf{S}_{1}$ & 15.22 & 16.58 & 695.22 & 722.53 & 562.00 & 586.95 & 80.83 & 81.24 & 5.69 & 5.95 & 1483.05 & 1583.08 & 3402.32 & 3503.32 \\
\hline $\mathbf{S}_{2}$ & 16.27 & 17.24 & 787.11 & 788.20 & 639.52 & 648.85 & 81.91 & 82.29 & 5.77 & 6.07 & 1707.43 & 1808.79 & 3721.85 & 3764.19 \\
\hline $\mathbf{S}_{3}$ & 17.38 & 18.24 & 807.33 & 815.87 & 665.27 & 675.19 & 82.37 & 82.69 & 5.99 & 6.38 & 2012.27 & 2111.25 & 3961.99 & 4095.31 \\
\hline $\mathbf{S}_{4}$ & 17.48 & 18.63 & 818.22 & 847.21 & 688.14 & 715.43 & 84.05 & 84.42 & 6.03 & 6.54 & 2115.59 & 2215.95 & 4180.03 & 4273.20 \\
\hline S.Ed & 0.12 & 0.12 & 5.06 & 7.52 & 5.11 & 6.85 & 0.14 & 0.17 & 0.015 & 0.017 & 29.10 & 29.92 & 17.16 & 20.59 \\
\hline $\mathrm{CD}(\mathrm{P}=0.05)$ & 0.25 & 0.26 & 10.18 & 15.12 & 10.28 & 13.78 & 0.30 & 0.35 & 0.032 & 0.036 & 58.51 & 60.15 & 33.26 & 41.39 \\
\hline \multicolumn{15}{|l|}{ Boron } \\
\hline $\mathbf{B}_{0}$ & 14.22 & 15.76 & 652.53 & 666.03 & 529.69 & 543.41 & 81.03 & 81.48 & 5.56 & 5.59 & 1135.67 & 1235.02 & 3257.10 & 3356.91 \\
\hline $\mathbf{B}_{1}$ & 16.72 & 17.74 & 792.00 & 809.05 & 642.21 & 662.18 & 81.32 & 81.67 & 5.90 & 6.29 & 1919.96 & 2020.05 & 3855.24 & 3970.34 \\
\hline $\mathbf{B}_{2}$ & 16.82 & 18.07 & 804.40 & 829.11 & 663.37 & 688.35 & 82.33 & 82.88 & 5.94 & 6.35 & 2001.00 & 2102.03 & 3932.01 & 4038.80 \\
\hline S.Ed & 0.09 & 0.11 & 4.78 & 7.01 & 4.54 & 6.18 & 0.13 & 0.16 & 0.014 & 0.016 & 25.47 & 27.91 & 16.54 & 20.03 \\
\hline $\begin{array}{c}\text { CD (P }= \\
0.05)\end{array}$ & 0.19 & 0.24 & 9.61 & 14.11 & 9.14 & 12.43 & 0.29 & 0.34 & 0.030 & 0.034 & 51.21 & 56.10 & 33.26 & 40.28 \\
\hline
\end{tabular}


International Journal of Scientific and Technological Research

www.iiste.org

ISSN 2422-8702 (Online), DOI: 10.7176/JSTR/5-11-01

Vol.5, No.11, 2019

\section{Quality characters (Table 2)}

\section{Oil content}

The oil content of sunflower seeds was significantly influenced by sulphur application. The highest oil content of 40.68 and 41.65 per cent was recorded with sulphur @ $60 \mathrm{~kg} \mathrm{~S} \mathrm{ha}^{-1}$ and the least value recorded under no $\mathrm{S}$ applied plot. Increase in oil content by sulphur application might be attributed to involvement of sulphur in the biosynthesis of oil (Mudd, 1967)

Oil content of sunflower seeds was significantly influenced by boron application. The maximum oil content of 39.82 and 40.87 per cent was recorded with application of boron @ $1 \mathrm{~kg} \mathrm{~B} \mathrm{ha}^{-1}$ and the least value recorded under the treatment $0 \mathrm{~kg} \mathrm{~B} \mathrm{ha}^{-1}$ applied plot. The increase in oil content in this treatment might be due to enhanced uptake of boron in the seed and had a significant effect on oil content in sunflower seeds. Similar results was reported by Battachary and Mandal (2009).

With regard to interaction, $60 \mathrm{~kg} \mathrm{~S} \mathrm{ka}^{-1}$ along with B @ $1 \mathrm{~kg} \mathrm{ha}^{-1}\left(\mathrm{~S}_{4} \mathrm{~B}_{2}\right)$ recorded higher oil content in both the crops. The enhance sulphur and boron content in seed had a positive and significant effect on oil content. Similar trend was observed by Survase et al. (1986). The lesser oil content was recorded under the treatment $\mathrm{S}_{0} \mathrm{~B}_{0}\left(0 \mathrm{~kg} \mathrm{~S}^{-1}\right.$ with $\left.\mathrm{B} @ 0 \mathrm{~kg} \mathrm{ha}^{-1}\right)$ might be due to poor uptake of sulphur and boron in the sunflower seed.

Table 2: Effect of different levels of sulphur and boron on quality of sunflower

\begin{tabular}{|c|c|c|c|c|}
\hline \multirow{2}{*}{ Treatments } & \multicolumn{2}{|c|}{ Oil content $(\%)$} & \multicolumn{2}{|c|}{ Crude protein content (\%) } \\
\hline & I crop & II Crop & I crop & II Crop \\
\hline \multicolumn{5}{|l|}{ Sulphur } \\
\hline $\mathbf{S}_{\mathbf{0}}$ & 37.67 & 38.19 & 23.76 & 24.51 \\
\hline $\mathbf{S}_{1}$ & 38.47 & 39.26 & 25.04 & 26.04 \\
\hline $\mathbf{S}_{\mathbf{2}}$ & 38.62 & 39.68 & 25.53 & 27.49 \\
\hline $\mathbf{S}_{3}$ & 39.48 & 40.34 & 26.39 & 28.04 \\
\hline $\mathbf{S}_{\mathbf{4}}$ & 40.68 & 41.65 & 26.85 & 28.65 \\
\hline S.Ed & 0.19 & 0.22 & 0.07 & 0.10 \\
\hline $\mathrm{CD}(\mathrm{P}=0.05)$ & 0.40 & 0.46 & 0.16 & 0.22 \\
\hline \multicolumn{5}{|l|}{ Boron } \\
\hline $\mathbf{B}_{0}$ & 37.83 & 38.45 & 24.18 & 25.20 \\
\hline $\mathbf{B}_{1}$ & 39.29 & 40.15 & 26.05 & 27.60 \\
\hline $\mathbf{B}_{2}$ & 39.82 & 40.87 & 26.26 & 28.04 \\
\hline S.Ed & 0.18 & 0.21 & 0.06 & 0.09 \\
\hline $\mathrm{CD}(\mathrm{P}=0.05)$ & 0.38 & 0.43 & 0.14 & 0.20 \\
\hline
\end{tabular}




\section{Crude protein content}

Among the different $S$ levels, the higher protein content of 27.31 and 29.36 per cent were registered with $\mathrm{S} @ 60 \mathrm{~kg} \mathrm{ha}^{-1}$ in both the crops than the other $\mathrm{S}$ levels. The lowest protein content was observed at $0 \mathrm{~kg}$ $\mathrm{S} \mathrm{ha}^{-1}$ in both the crops. The relative increase in protein content with $\mathrm{S}$ application might be due to increased availability of $S$ for subsequent synthesis of oil and protein. Similar findings were reported by Chitkala and Reddy (1991).

Among the different B levels, the maximum crude protein content of 27.06 and 29.05 per cent was recorded in the treatment received B @ $1 \mathrm{~kg} \mathrm{ha}^{-1}$ over the other levels. The increased protein content in this treatment might be due to the highest uptake nitrogen by seed and $\mathrm{N}$, might have been incorporated in the protein molecule of the protein content of seed was significantly higher for agribor compared to boric acid. Similar findings were reported by (Ramamoorthy and Sudrasan, 1992).

Among the different treatment combination, $60 \mathrm{~kg} \mathrm{~S} \mathrm{ha}^{-1}$ with B @ $1 \mathrm{~kg} \mathrm{ha}^{-1}$ produced maximum protein content. The least protein content was observed in $\mathrm{S}_{0} \mathrm{~B}_{0}\left(0 \mathrm{~kg} \mathrm{~S} \mathrm{ha}^{-1}\right.$ with B @ $\left.0 \mathrm{~kg} \mathrm{ha}^{-1}\right)$.

\section{Nutrient uptake (Table 3)}

Maximum N, P, K and S uptake was registered under $60 \mathrm{~kg} \mathrm{~S} \mathrm{ha}^{-1}$. This might be due to optimum rate of sulphur application. This may be attributed to increased uptake of N, P, K and S, ultimately more utilization of these nutrients, which enhanced their concentration and uptake (Bhagat et al., 2003).

Among the boron levels, maximum N, P, K and S uptake was recorded under the B @ $1 \mathrm{~kg} \mathrm{ha}^{-1}$. The least uptake of $\mathrm{N}, \mathrm{P}, \mathrm{K}$ and $\mathrm{S}$ was observed with $0 \mathrm{~kg} \mathrm{~B} \mathrm{ha}^{-1}$. The results are in conformity with the findings of Kumar et al. (1996).

The interaction effects between sulphur and boron were significant. The highest nutrient uptake of N, P, $\mathrm{K}$ and $\mathrm{S}$ was noticed under S @ $60 \mathrm{~kg} \mathrm{ha}^{-1}$ with B @ $1 \mathrm{~kg} \mathrm{ha}^{-1}$. This could be due to optimum quantity of sulphur and boron application and their easy availability to the crops. Increased uptake of S was mainly due to increase of its concentration in plant tissues (Martre et al., 2009).

\section{Post harvest soil nutrient available nutrients (Table 3)}

Application of sulphur @ $0 \mathrm{~kg} \mathrm{ha}^{-1}$ registered maximum post harvest soil nutrient available N, P, K while sulphur at $15 \mathrm{~kg} \mathrm{ha}^{-1}$ recorded maximum $\mathrm{S}$ in post harvest soil. This might be due to poor uptake of N,P and $\mathrm{K}$ under no sulphur applied plot compared to other $\mathrm{S}$ levels. $15 \mathrm{~kg} \mathrm{~S} \mathrm{ha}^{-1}$ recorded poor sulphur uptake and hence it increased the availability sulphur. Similar results were also reported by Krishnaprabhu (2006).

Among the $\mathrm{B}$ levels, $0 \mathrm{~kg} \mathrm{~B} \mathrm{ha}^{-1}$ recorded the highest post harvest soil available nutrient of $\mathrm{N}, \mathrm{P}, \mathrm{K}$ and recorded $B_{2}$ recorded highest $S$ availability. The least values for $N, P, K$ were recorded under $B_{2}$ and $S$ is minimum in $\mathrm{B}_{0}$.

The interaction effect between sulphur and boron was found to be significant. The maximum amount of $\mathrm{N}, \mathrm{P}, \mathrm{K}$ and $\mathrm{S}$ was available in S @ $15 \mathrm{~kg} \mathrm{ha}^{-1}$ with B @ $0.5 \mathrm{~kg} \mathrm{ha}^{-1}$. The least value was recorded under

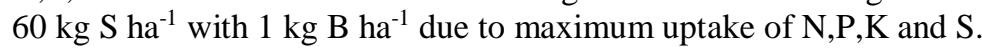


International Journal of Scientific and Technological Research ISSN 2422-8702 (Online), DOI: 10.7176/JSTR/5-11-01

Vol.5, No.11, 2019 www.iiste.org

$\| \mathbb{S u}_{\mathrm{E}}$

Table 3: Effect of different levels of sulphur and boron on nutrient uptake, post harvest soil nutrient status and of sunflower

\begin{tabular}{|c|c|c|c|c|c|c|c|c|c|c|c|c|c|c|c|c|}
\hline \multirow{3}{*}{ Treatments } & \multicolumn{8}{|c|}{ Nutrient uptake $\left(\mathrm{Kg} \mathrm{ha}^{-1}\right)$} & \multicolumn{8}{|c|}{ Nutrient availability $\left(\mathrm{Kg} \mathrm{ha}^{-1}\right)$} \\
\hline & \multicolumn{2}{|c|}{$\mathbf{N}$} & \multicolumn{2}{|c|}{$\mathbf{P}$} & \multicolumn{2}{|c|}{$\mathbf{K}$} & \multicolumn{2}{|c|}{$\mathbf{S}$} & \multicolumn{2}{|c|}{$\mathbf{N}$} & \multicolumn{2}{|c|}{$\mathbf{P}$} & \multicolumn{2}{|l|}{$\mathbf{K}$} & \multicolumn{2}{|l|}{$S$} \\
\hline & $\begin{array}{c}\text { I } \\
\text { crop }\end{array}$ & $\begin{array}{c}\text { II } \\
\text { Crop }\end{array}$ & I crop & $\begin{array}{c}\text { II } \\
\text { Crop }\end{array}$ & $\begin{array}{c}\text { I } \\
\text { crop }\end{array}$ & $\begin{array}{c}\text { II } \\
\text { Crop }\end{array}$ & $\begin{array}{c}\text { I } \\
\text { crop }\end{array}$ & $\begin{array}{c}\text { II } \\
\text { Crop }\end{array}$ & I crop & II Crop & I crop & II Crop & I crop & \begin{tabular}{|l|} 
II \\
Crop
\end{tabular} & I crop & II Crop \\
\hline \multicolumn{17}{|l|}{ Sulphur } \\
\hline $\mathbf{S}_{\mathbf{0}}$ & 70.94 & 73.00 & 17.22 & 16.06 & 68.94 & 65.84 & 10.47 & 11.49 & 233.26 & 237.17 & 21.74 & 20.68 & 339.22 & 337.37 & 16.85 & 17.78 \\
\hline $\mathbf{S}_{\mathbf{1}}$ & 72.50 & 74.39 & 17.94 & 16.67 & 66.99 & 66.62 & 11.81 & 11.49 & 224.85 & 229.51 & 19.64 & 18.54 & 330.05 & 327.87 & 20.28 & 21.27 \\
\hline $\mathbf{S}_{2}$ & 74.05 & 76.18 & 18.81 & 18.02 & 68.25 & 68.83 & 12.75 & 12.87 & 218.23 & 223.33 & 17.87 & 17.22 & 324.21 & 322.19 & 19.23 & 20.54 \\
\hline $\mathbf{S}_{3}$ & 76.11 & 77.78 & 19.75 & 19.26 & 70.00 & 70.30 & 13.52 & 14.53 & 210.34 & 214.30 & 17.22 & 16.30 & 312.83 & 311.06 & 17.60 & 18.70 \\
\hline $\mathbf{S}_{4}$ & 77.40 & 79.18 & 20.60 & 20.65 & 70.71 & 71.53 & 13.81 & 14.89 & 193.66 & 197.65 & 15.59 & 14.49 & 306.18 & 304.31 & 16.54 & 17.51 \\
\hline S.Ed & 0.41 & 0.42 & 0.17 & 0.18 & 0.32 & 0.33 & 0.13 & 0.16 & 0.70 & 0.72 & 0.21 & 0.24 & 0.52 & 0.60 & 0.16 & 0.33 \\
\hline $\begin{array}{c}\mathrm{CD}(\mathbf{P}= \\
0.05)\end{array}$ & 0.83 & 0.85 & 0.36 & 0.38 & 0.65 & 0.68 & 0.27 & 0.34 & 1.42 & 1.45 & 0.43 & 0.50 & 1.05 & 1.21 & 0.34 & 0.68 \\
\hline \multicolumn{17}{|l|}{ Boron } \\
\hline $\mathbf{B}_{0}$ & 71.26 & 73.25 & 16.98 & 15.97 & 65.08 & 66.26 & 10.73 & 11.88 & 217.59 & 221.65 & 19.46 & 18.30 & 324.98 & 323.04 & 17.06 & 18.02 \\
\hline $\mathbf{B}_{1}$ & 75.26 & 76.92 & 19.55 & 16.71 & 69.45 & 69.37 & 13.27 & 14.23 & 216.69 & 220.64 & 18.47 & 17.67 & 322.46 & 320.46 & 17.98 & 19.18 \\
\hline $\mathbf{B}_{2}$ & 76.09 & 78.15 & 20.08 & 19.72 & 69.94 & 70.24 & 13.42 & 14.62 & 213.91 & 218.28 & 17.30 & 16.37 & 320.06 & 318.18 & 19.26 & 20.36 \\
\hline S.Ed & 0.39 & 0.40 & 0.13 & 0.14 & 0.22 & 0.23 & 0.10 & 0.15 & 0.69 & 0.71 & 0.20 & 0.23 & 0.51 & 0.59 & 0.15 & 0.32 \\
\hline $\begin{array}{c}\mathrm{CD}(\mathrm{P}= \\
0.05)\end{array}$ & 0.80 & 0.82 & 0.28 & 0.30 & 0.45 & 0.47 & 0.21 & 0.32 & 1.40 & 1.44 & 0.41 & 0.48 & 1.04 & 1.20 & 0.32 & 0.66 \\
\hline
\end{tabular}




\section{REFERENCES}

Asad, A., F.P.C. Balmey and D.G. Edwards. 2002. Dry matter production and boron concentrations of vegetative reproductive tissues of canola and sunflower plants grown in nutrient solution. Plant. Soil., 243: 243-252.

Asad, A., F.P.C. Balmey and D.G. Edwards. 2003. Effect of boron foliar application on veagetative and reproductive growth of sunflower. Ann. Bot., 92: 565-570.

Bhagat, G.J., Abdul Hamid, S.P. Bonde, M.D. Giri and M. Sajid. 2003. Effect of irrigation and sulphur on growth and yield attributes of rabi sunflower (Helianthus annuus L.). Res. on Crop, 4(1): 56-59.

Bhattacharya, T.K. and N.C. Madal. 2009. Management of culb rot of rapseed and mustard by fertilizers. Ann. Plant Protec. Sci., 14: 260-261.

Belvins, D.G., and K.M. Lukaszewski. 1998. Boron in plant structure and function. Plant Physiol., 49: 481-500.

Blamey, F.P.C., R.K. Zollinger and A.A.A Schneiter. 1997. In sunflower technology and sunflower production and culture. American Society of Agronomy, Madison, WI, USA. Pp.595-670.

Chitkala, T.D. and M.G. Reddy. 1991. Effect of gypsum and P fertilizer on groundnut. Indian J. Agronomy, 47(3):345-349.

Jamal, A., I.S. Fazli, S.Ahmad, M.Z. Abdin and S.J. Yun. 2005. Effect of sulphur and nitrogen application on growth characteristics, seed and oil yield of soybean cultivars. Korean J. Crop Sci., 50(5): 340-345.

Intodia, S.K. and O.P. Tomar. 1997. Effect of sulphur application on growth and yield of sunflower (Helianthus annuus L.). Indian J. Agri. Sci., 67(1): 46-47.

Krishnaprabu, S. 2006. Agronomic strategies for yield maximization of sesame in rice fallow. Ph.D. (Ag.). Thesis, Annamalai Univ, Tamil Nadu, India.

Kumar, A., K.. Singh, R,P. Singh and A.K. Srker, 1996. Response of groundnut of boron application in acid sedentary soil. J. Indian Soc. Soil Sci., 44: 178-179.

Messick, D.L. 2003. Sulphur fertilizers a global perspective, pp 1-7. In: proceeding of TSI-FAI-IFA workshop on sulphur balanced fertilization.

Martre, L.A.P., G. Pereyra-Irujo, N. Izquierdo and V. Allard. 2009. Management and breeding strategies for the the improvement of grain and oil quality. Crop Physiology pp.387-421.

Mudd, J.B. 1967. Fat metabolism in plants. Ann. Plant Physiol., 18: 229-252.

Raja, A., K. Omar Hattab, L. Guruswamy, G. Vembu and K.S. Suganya. 2007. Sulphur application on growth and yield and quality of sesame varieties. Intl. J, Agri. Res., 2: 599-606.

Ramamoorthy,K. and S. Sudarsan. 1992. Supply of zinc and boron on yield and seed quality in groundnut. Ann. Plant Physiol., 6: 33-38.

Renukadevi, A. and P. Savithri. 2003. Sunflower (Helianthus annuus L.) oil yield and quality as influenced by boron application. Madras Agric. J., 91: 74-96.

Sakal, R., A.P. Singh, B.C. Choudhary and B. Shahi. 2001. Sulphur status of usifluvents and response of crops to sulphur application. Fertilizer news 46(10): 61-65. 
Sinha, R.B., P. Sakal and S. Kumar. 1995. Sulphur and phosphorus nutrition of winter maize in calcareous soil. J. Ind. Soc. Soil Sci., 43(3): 413-418.

Survase, D.N., J.H. Dongale and S.B. Kadrekar. 1896. Growth, yield, quality and composition of groundnut as influenced by FYM, calcium, sulphur and boron in lateritic soils. J. Maharastra Agric. Univ., 11: 49-51.

Syed Shujat Hussain, F.A. Misger, Amit Kumar and M.H. Bala. 2001. Response of nitrogen and sulphur on biological and economic yield of sunflower (Helianthus annuus L.). Research J. Agric. Sci., 2(22): 308-310. 